\title{
TRANSFERRING LEARNED KNOWLEDGE FROM THE BANG PLEE NEW TOWN OF THAILAND: CONCEPTS AND POLICIES
}

\author{
CHAWEEWAN DENPAIBOON, PORNCHAI JANTAWORN, \\ PATTAMON SELANON \& YANISA BOONNUN \\ Thammasat University, Thailand
}

\begin{abstract}
This study aims to analyze the socioeconomic impacts on spatial patterns of growth as well as urban land management, efficiency, and productivity of urban centers, and to study a changing house type of sites and services in Bang Plee New Town along with an examination concerning a relation of the theme of community creation in New Town. The study is based on primary and secondary data sources. Primary data was collected through face-to-face household head questionnaire surveys and field observation. After a vigorous analysis of primary and secondary data and information, the study suggested that the sites and services scheme became the byword for solving the problem of high-rise settlements. There are a vast diverse of sites and services schemes, ranging from the subdivided plot to a serviced plot of land. Complete serviced house by government sectors is not possible or affordable by most low-income families. Therefore, the focus is shifted from supplying a fully serviced house to providing only serviced land. The key of this approach is the use of internal resources, particularly, the beneficiaries, sweat equity and others such as community, financial, etc., in the actual construction and development of the houses. The sites and services scheme has emphasized that housing is a basic need of people and that investment in housing has an important role to play in the economic and social development of the country.

Keywords: lesson learn, New Town, sites and services, concepts and policies.
\end{abstract}

\section{INTRODUCTION}

Thailand's urban population almost quadrupled between 1960 and 1990. The total population more than doubled over time. Likewise, the percentage of people living in urban areas, only 13 per cent in 1960, is projected to reach 30 per cent in 2020, with an average annual urban population growth of 3.5 per cent between 1990 and 2020 with 4 reasons as follows; i) to solve urban sprawl of large cities like the greater Bangkok, ii) indispensability of the socioeconomic activities of a certain territory, iii) to necessitate the demand of more compact regional settlement network, and the last is the reclamation of economic (industrial) or employment. Bang Plee New Town project is the pioneer one of Thai Government that initiated in 1972. In the early 1960s, new town construction steam has been the first idea implemented by the National Housing Authority as a state enterprise under increasing population into greater Bangkok, it conceived a city plan for which a sufficiency expansive urbanization. It would be chosen in the outskirt of a large-scale project which is located 40 $\mathrm{km}$ far from the center of Bangkok. Development of new town scheme consists of concept social and economic development of providing housing and job balance in order to plan in self-contained the project. A new town in Thailand is a targeted community oriented functioning independently and self- support with housing, commercial activities or largescale employment opportunities but has to have faced various challenges.

Bang Plee New Town project is the first time at a giving moment had certain the first new town development by the government with their specific features and the problem of further progress. Planning analyst in the new town of Thailand do pay attention to investigation around new towns became already a usual component of land used and urbanites space in 
numerous in Bangkok Metropolitans Regions. The working place is very attractive for labor force influencing investors. Apparently, it is high time to summarize the experience of new town formation, to consider its various aspects to present a conceptual and realistic analysis of new town development in the future in different countries as well as numerous problems faced by new town. The dimension of new town may vary. This necessarily subjective definition is our understanding of what the New Town was setting out to create without employment in the first period, in bringing new residents together in newly built settlements. The questions raised in the brief relating to the impact of community creation were:

1. What worked and didn't work in terms of community master planning?

2. How did the physical environment and housing change in the creation of communities?

3. How have the existing communities changed over time, and are there any positive and negative implications to this?

Each of these questions is addressed sequentially below from the literature review. This provides the basis for then inferring possible transferable lessons with regard to the broad theme of creating communities for the Growth Areas Programme.

\section{THE PURPOSE OF THE PAPER}

This paper is to reveal lesson learned from the new town development in Thailand from the concepts and policies than to propose basic concepts of new town driving of all this material. The objectives of this research are to 1) analyze the socioeconomic impacts on spatial patterns of growth as well as urban land management, efficiency, and productivity of urban centers and to study a changing house type of sites and services in Bang Plee New Town along with to study concerning a relation of the theme of community creation in New Town.

\section{THE METHODOLOGY OF THE STUDY}

The study derives from the current theoretical and practical concept of satellites town systems development and functioning, popular now in economic and social geography in an urban building, sociology, demography, the economic geographical situation of the town and management of urban development and settlement have been overviewed. In this study assumed as a basic much conceptual and methodology and investigation. As information base for primary statistical data has taken as well as monographs and article. Therefore, new town satellites were used to assess.

\section{THEORETICAL AND METHODOLOGICAL ASPECTS OF NEW TOWN RESEARCH}

This study starts from Thomas or Cullingworth and Karn's New Town concept, which focused mainly on key social and economic objectives, especially in the early London New Towns [1]. The concept typically dealt with issues such as the extent of commuting to the new towns and the degree of employment, 'self-containment' or 'social balance'. Much more complicated is to define a new town with the help of functional criteria. The concept of a town itself means a multi-functional settlement. The definition in its traditional meaning refer to old towns that lack independents significance (town - satellites being the first to exclude) and being adjacent to large cities or their agglomeration perform some special functions, instance, of residential areas (town - "bedroom") and job opportunity [1] (see Fig. 1).

The review of the "new town" concept is schematic outlining only major trends. In reality, there are many other features, alongside with basic ones-revealed and quantified according 
to criteria discussed, which are difficult to adequately differentiate and characterize. It is worth to notice that the "New Town" to settlement, that partially or completely appeared at the so-called "bare place" in the last 30-50 years, that kind of settlement should be spatially isolated from its surrounding, due to an administrative discussion, which was materialized in an urbanicity plan and specific architecture [2]. The residents of such settlement, which are demographically young have to earn their living by various non-agriculture occupations and experience feelings of community with their neighbor and with the place they live.

Two concepts appear to stand out in the planning and building of New Town: one is selfcontainment and the other, particularly in the industrial township, is the image of a model employer. However, the meaning of self-containment in the new towns is quite often the term "self-sufficient" do not be dependent on some other city that consists of not only business and industries but also factories, shops, and services meeting local need established in the new town. A self-contained area can be defined as an area which contains complete range of urban facilities, i.e., sufficient employment, shopping, health, education and other facilities for the number of residents [3]. A self-contained area in a social aspect, can also be defined as an area in which the town's people can live full life satisfying all their daily needs within the new town that provide the environment for the life of a complete community [3].

\section{COMPONENTS OF NEW TOWN PROJECT}

Bang Plee New Town Project was Metropolis's Satellite town which is located 23 Kilometers, the East side of Bangkok on Bang Na-Trad Highway, Bang Sao Tong Subdistrict, Bang Plee District, Samutprakarn Province. Although the new town Project started in the 1970s, it was developed much more slowly due to its long distance from urban Bangkok City and workplace, Commuters needed to travel via other areas like Bus and Mini Bus with no rail transport. With the rapid development of an adjacent new town Project Phase I, Industrial estate, in the 1980s, the road network was drastically improved by the late 1990s. Population in Bang Plee New Town, it is expected that there are totally 25,000 households or approximately more 120,000 inhabitants; it will be 40,000 labor force [4] (see Fig. 2). Current populations are approximately 140,000 persons (Municipal Bang Sao Thong, [14]). Moreover, urban utilities consist of a flood protection, drainage system, waste water treatment, water supply, garbage collection, electricity, telephone, and also urban facilities are education, recreation, community services.

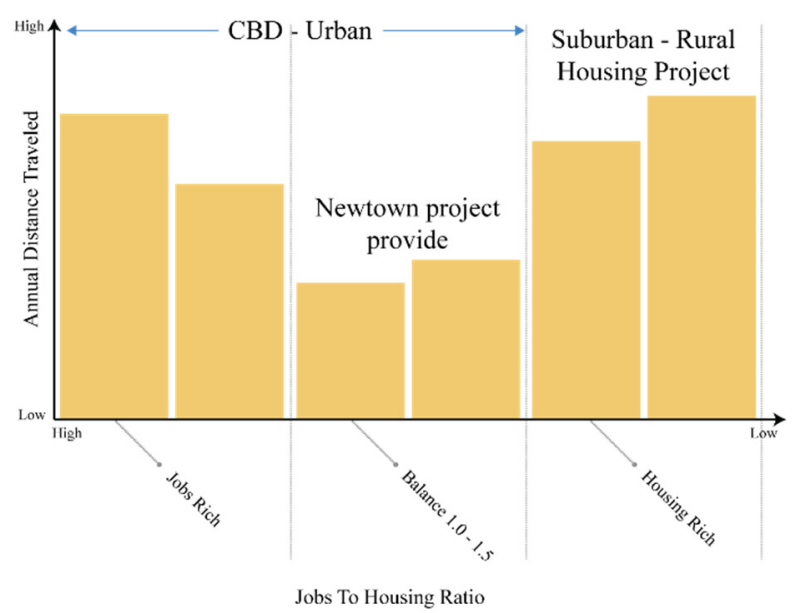

Figure 1: Jobs-housing balance concept. (Source: Cervero, [13].) 


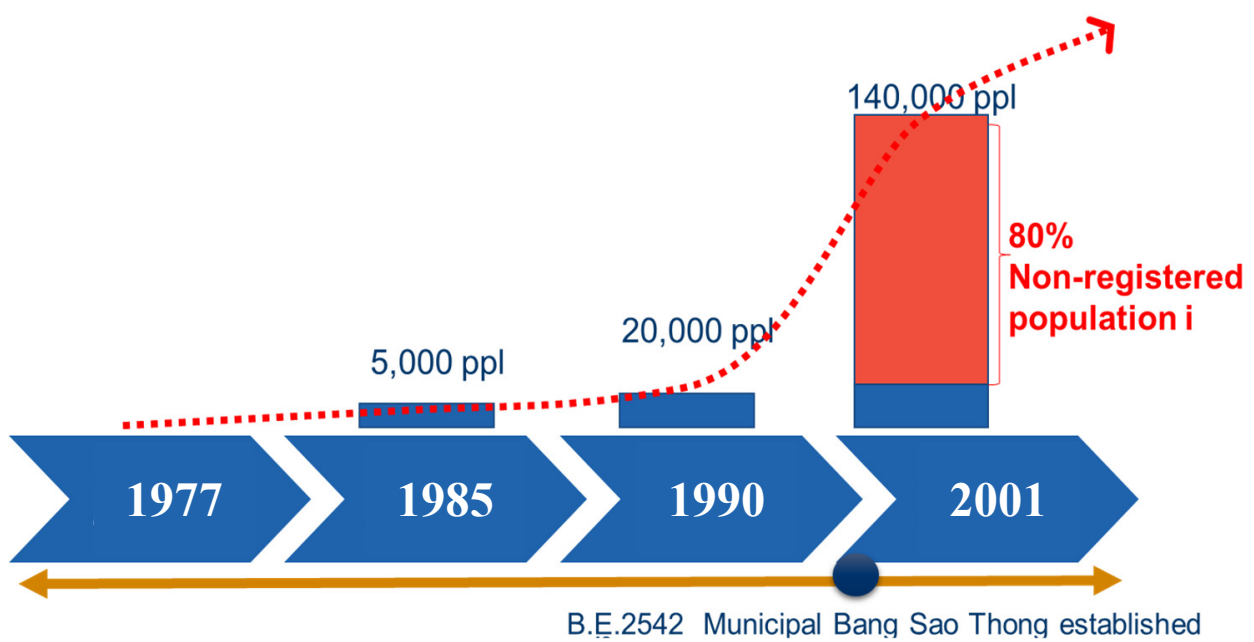

Figure 2: Estimation of population in municipal Bang Sao Thong. (Source: Municipal Bang Sao Thong, [14].)

\section{IN MASTER PLAN OF NEW TOWN DEVELOPMENT}

For the purpose of this study, a new Town is taken as a town/ newly built settlement with economic self-containment, this would mean a town constructed on a lowland field site or on a site practically uninhabited before when Bang Plee New Town built for low-income housing project with sites and services concept by the National Housing Authority since 1972 and allocated inhabitants in 1975. After housing development completed Industrial Estate Authority built factories.

\section{MEASURES OF PLOT RATIO AND BUILDING DENSITY}

In planned of Bang Plee New Town, plot ratio is extensively adopted as 4 types (See Table 1) of housing for the regulation of land-use zoning and development control. Different plot ratios for different types of housing are often specified in master plans as a provision of core housing development. The total floor area usually takes into account the entire area within the perimeter of the exterior walls of the building, which includes the thickness of internal and external walls, stairs, service ducts, lift shafts, all circulation spaces, and so on. Furthermore, maximum plot ratio is often controlled in the master plan in order to govern the extent of build-up and overdevelopment by plot ratio of the total gross floor area of a developed to its plot area (see Table 2). Site area refers to the total lot area of the development, which, in most cases, is precisely defined in the planning document. Since the definitions of both floor and site areas are relatively clear in the measurement, plot ratio is considered as one of the most unambiguous density measures.

\section{RESULT AND DISCUSSION}

The conclusion on points raised in the literature:

How can integrated communities be developed housing and transformation? It was recognized early on in the first generation of New Towns that 'creating communities' would be an important component to the success of the New Towns policy. Bang Plee New Town needed to have a sense of belonging for people who had come from diverse backgrounds and 
Table 1: Spatial characteristics of core housing units (provided). (Source: Adapted from the National Housing Authority, 1980.)

\begin{tabular}{|c|c|c|c|c|}
\hline $\begin{array}{l}\text { Provided } \\
\text { housing type }\end{array}$ & & & & \\
\hline $\begin{array}{l}\text { House type } \\
\text { (Rowhouse) }\end{array}$ & A: One-storey & B: Two-storey & $\begin{array}{c}\text { C: Semi- } \\
\text { detached two- } \\
\text { storeys }\end{array}$ & $\begin{array}{c}\text { D: Semi- } \\
\text { detached two- } \\
\text { storey }\end{array}$ \\
\hline $\begin{array}{l}\text { Plot sizes (sq. } \\
\text { m.) }\end{array}$ & $\begin{array}{c}84.00 \\
(4.2 \times 20 \mathrm{~m} .)\end{array}$ & $\begin{array}{c}84.00 \\
(4.2 \times 20 \mathrm{~m} .)\end{array}$ & $\begin{array}{c}160.00 \\
(8 \times 20 \mathrm{~m} .)\end{array}$ & $\begin{array}{c}200.00 \\
(10 \times 20 \mathrm{~m} .)\end{array}$ \\
\hline $\begin{array}{l}\text { BLDG sizes } \\
\text { (sq. m.) }\end{array}$ & 25.20 & 37.80 & 60.00 & 84.42 \\
\hline FAR & 0.30 & 0.45 & 0.38 & 0.42 \\
\hline $\begin{array}{l}\text { Road width } \\
\text { (mates) }\end{array}$ & $6,7.5$ & $6,7.5$ & $7.5,14$ & $7.5,14$ \\
\hline \multicolumn{5}{|c|}{ Whole project's data. } \\
\hline Households & 5205.00 & & & \\
\hline Population & 31230.00 & & & \\
\hline $\begin{array}{l}\text { Population } \\
\text { density(NET) }\end{array}$ & \multicolumn{4}{|c|}{13.24 families per Rai } \\
\hline
\end{tabular}

Table 2: Housing transformed types. (Source: Adapted from the National Housing Authority, 1980.)

Housing
Transformed
type of A:
One-storey
and B: Two-
storey

places. The Bang Plee New Town also needs to provide local people an opportunity to participate in the development process by gradually house developing of their own household socioeconomic. These sites and services or core house are in type A, type B, type C, (see 
Table 2) Social/Community Development Officers and their teams played a vital role in creating communities, ensuring information reached people for example through distributing newsletter in New Town, and that individuals were involved as far as possible in decisionmaking as the settlement grew [5]. Local authority offices were set up, regulation of living in a house within a new neighborhood, to act as a point of information, and as a base from which Community Development Officers could call in on new residents. In order to facilitate new residents' involvement in decision-making, a neighborhood groups were also set up. Voluntary organizations were also seen as a vital means of creating integrated communities [6]. In areas where there was an existing.

However, most people moving into New Towns had young families, and with the pressures of work, family and settling into a new place, there was often little time for people to get involved in community issues. Those that did have time tended to be women and foreign women nearby countries live and work. Residents recognized that their role was not just to seek jobs and houses for them, but they were also responsible for building community facilities and the social infrastructure that goes to make up a 'living community'. Sports facilities were built within communities, rather than on the periphery, and playgrounds and facilities for children were integrated into the neighborhood. Local authority to this was the idea of 'walking distance communities where each neighborhood would have its own primary school, a parade of shops, post office, chemist, church, pub, community center and sports facilities. Schools played an important role in the community, partly because of a large number of young families moving to the New Towns, but also as the school buildings themselves were used as centers for other social facilities, such as pre-school and health centers. This provision of multiple-use facilities was seen by some habitats as a key to making walking distance communities work.

An important factor in the creation of communities is the housing stock that is provided; initially, most housings in the New Town was built for particularly in terms of tenure to buy and provides public sector. A full scale of job opportunity development happened, the migration of labor force from neighbor countries come to the New Town as well as a housing shortage. Hence, rental housing continually was occurred both a low-rise and high-rise buildings in Bangkok new town during 1997 until now. There is a phenomenon of sites and services schemes1 transformation to informal vertical building (see Figs 2 and 3). Therefore, there was no control over the process. Housing management techniques and practices, and provision for tenants, thus, had a major influence in the make-up of the community. Consequently, there was a shift towards a greater mix of homes built for owner occupation partly as a result of shifts in economic crisis and government thinking about housing provision. Uncontrolled housing regulation in Bang Plee New Town Satellites for high rise building belong to private homes for rental housing and made a clear commitment to mixing housing types, tenure, and occupational groups, within the grid squares [7]. This was in response to earlier New Towns that were dominated by the housing for rent, which thus failed to attract the low-income classes. Subsequently, the Bang Plee New Town was characterized by a greater mix of social groups than previous New Towns.

The New Towns were created on industrial development sites, but in most cases, there was already at least a big scale existing community living in the area. In the case of Bang Plee New Town, the existing population was substantial, at 140,000 inhabitants (registration and un-registration). Although the evidence is limited, this study has also demonstrated that there was some tension between the newly arrived residents and the existing community [8]. Experiencing from previous research, it is recommended to treat the existing residents as being of equal importance as the new ones and to recognize the strong feelings that the establishment of a New Town can arouse in existing residents. 


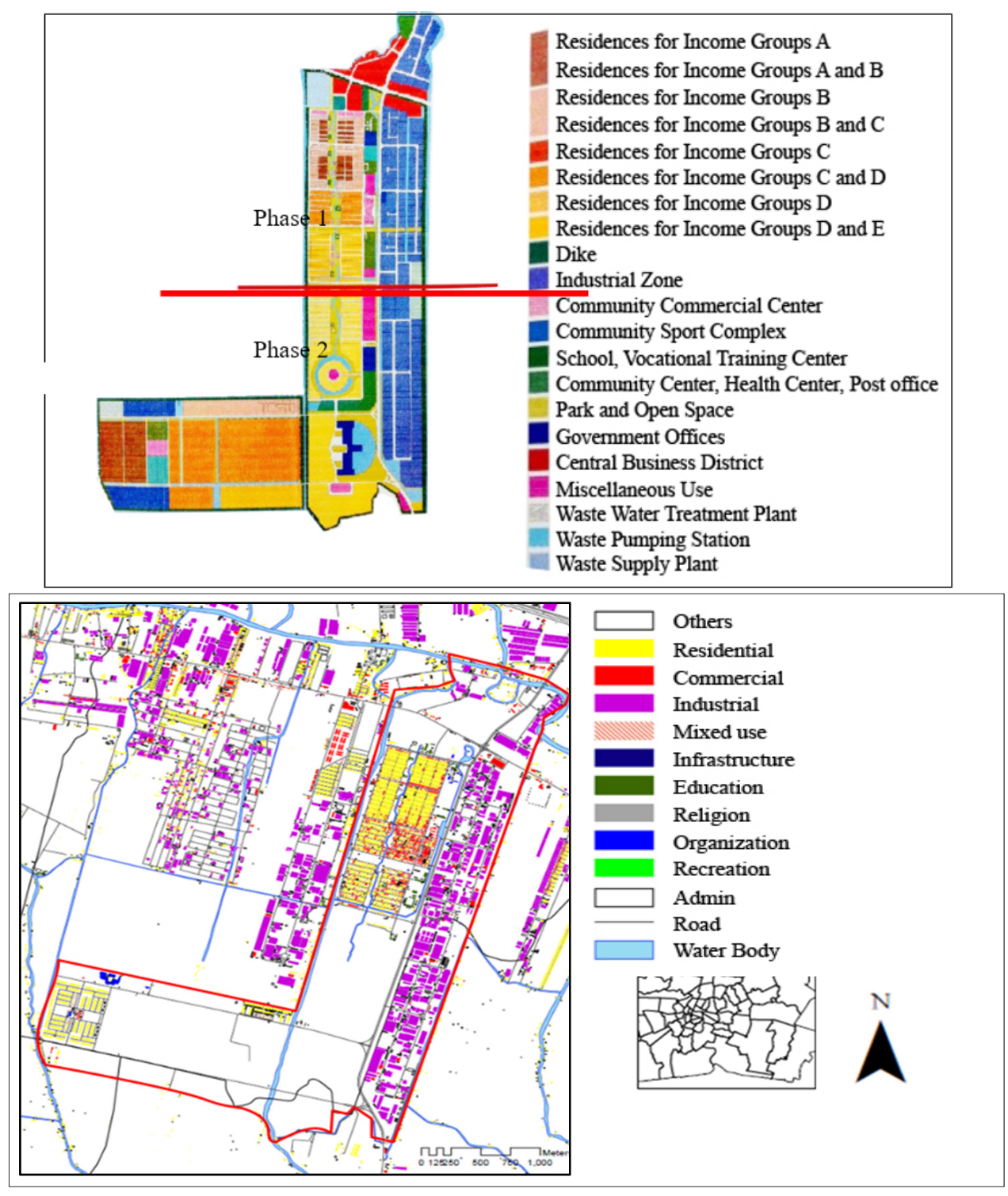

Figure 3: Bang Plee New Town master plan and existing land use. (The year 2003.) (Source: Adapted from the National Housing Authority, 1980.)

A successful approach was to provide the infrastructure that was flexible so that communities could develop it in a way that suited them in the future.

Those aspects that were less successful included the following:

In terms of social infrastructure, providing facilities weren't easily adaptable. The tendency was in designing and physical issues to dominate the planning process with community/social provision falling off the agenda. According to transfer urban management, belong to Municipality of Bang Sao Thong, it has a lack of skill urban management. 
Table 3: Existing plot ratio and building developed. (Source: Adapted from the National Housing Authority, 1980.)

\begin{tabular}{l|l|l|l|}
\hline &
\end{tabular}

How did the physical environment and housing help or hinder the creation of communities? The study's findings highlighted above have addressed many of the issues relating to the physical environment and housing and their role in the creation of communities. There is a particular note notion of 'walking distance communities' and the important role that local social infrastructure such as shops, playgrounds, and sports facilities) played in creating communities. Some evidences suggested that these facilities were already in place when people began to arrive. Therefore, the community came together and networks were formed more readily. 
Regarding the issue of zoning, there is mixed evidences of whether the physical separation of uses in the New Towns had an impact on social interaction. Some evidences demonstrated that there were much more powerful forces, such as housing status or socioeconomic status, which influenced social interaction and ultimately, community cohesion [9], [10]. This issue could be beneficial to future research. In terms of housing, the majority of housing in the first generation of the New Towns was built as social housing for rent. Subsequently, waves of the New Towns aimed to provide a greater mix of housing type and tenure. However, there has been little research into whether the different types of housing in the New Towns had an impact on the creation of communities. As the above noted, the lack of housing specifically catering for the elderly population has become a vital issue in study of the New Towns [11].

As noted by Harman and Joy [11], the social and cultural context of society today lies in the light of the post-war years. In the 1950s, many countries across the globe were still very much marked by the experiences of wartime, and this was reflected in the communalism and spirit of 'shared effort' that imbued the thinking of those moving to and setting up in the New Towns. This contrasts starkly in today's society, which was characterized more by 'individualism' and 'materialism' than 'mend and make do'. It may be worth noting that the New Towns were very different in character and context, and these differences can be of equal importance as the universal lessons that emerge. Nevertheless, some of the lessons that come out of the literature would appear to have relevance to today's context, with the caveat that further research would be needed to test their applicability in the proposed Growth Areas.

\section{TRANSFER LESSON LEARNT}

Bang Plee New Town Project is presented a form of over 50 years old were transferable lessons concept the master plan, and policies. These are presented with a brief observation about their relative significance and whether they imply an action or simply some acknowledgment as a background condition or factor that might inform future planning decisions for the Growth Areas. The second set of findings is presented as an identification of gaps in the evidence base, and as topics for possible future research. It is our view for survey and evaluate during 2016-2017, the results found 3 issues impacts on land used development and rethinking policies as follows;

1. The concept of sites and services; housing design for low-income group related with land tenure development impacts on urban development. According to sites and services concept and socio-economic vulnerability and land tenure, it is not good efficiency policies such kind of provide rental housing for them.

2. Job and housing imbalance in starting New town; the residents did not find a job in a new town project and after ten years full employment that is many labor force demand.

3. New Town is not the Nationality but is a big housing project because there is separate urban management. The National Housing Authority has planned for housing improvement and arrangement of eldery people in New Town Project.

4. Lack of housing development for the future.

In addition, the study has recommended to the National Housing Authority redevelopment new town become old.

\section{SUMMARY AND CONCLUSION}

The conclusions and possible approach discussion in this article might be summarized as follows:

- No town can be truly self-contained. The dominant industry based on private investors is an anachronism. The economic and social diversification that takes 
place in town is a part of its growth and its impact rules out local authority-based approach to town building and maintenance, the local authority has a lack of skill to operate town.

- The norm and standards should be closely related to evolving out living habit and actual requirements of the people their affordability. Subsidies and low cost only services increase the disparity between groups of people in the town

- Land and land use policies are tools and not end themselves in themselves. Given the past and current experience it will never be possible for industry to provide housing by public housing, the spread of poverty and the characteristic migration, marginal settlements are inevitable in New Town

- Space for recreation has to be devised in the functioning sense. The location of space, its accessibility and its safe use by children are far more important than town planner's stipulation of given

- Forms of shopping space and pricing for such space should be realistic. Native styles of retail trade which permit variety in merchandise and enable the spread of selfemployment should be encouraged.

- Transportation is not a matter of just circulation space. Mode and cost transportation are important. Pedestrian and bicycle scale are more appreciate in planning transportation in the New Town.

\section{APPLICATION OF THE PRESENT RESEARCH}

The author recalls the point being made was in a new town, the lessons learned in Bang Plee New Town had been remembered. This is true for government. Whether in Housing Project, the valuable lessons of the past four decades in the planning, building, and upkeep of industry, are remembered and applied. Similar lessons have been learned in the new town as well.

If the lessons contained in this report are to be applied, those charged with applying them may need some training or guidance - on an area by area basis. This would serve two purposes: first to ensure the lessons are properly understood; and second to provide an opportunity for the Growth Area teams to raise issues specific to their own development, planning, finance and locational contexts.

\section{NOTES}

${ }^{1}$ Sites-and-services scheme; is a shift of focus from the provision of a complete house to the provision of a serviced plot and the delegation of the responsibility for the construction of the house to the allottee [12]. The purest form of a sites-and-services scheme is an urban residential land subdivision where the developer sells or leases serviced plots, i.e. land with basic infrastructure (roads, water supply, drainage, a human waste disposal system, electricity) to a specific target group: low-income households.

${ }^{2}$ Sites and services scheme has been emphasized that housing is people's basic needs and that investment in housing has an important role to play in the economic and social development. It is within this context that the provision of housing is viewed from two broad philosophical perspectives.

\section{ACKNOWLEDGEMENTS}

This paper reports part of the research findings of research project entitled "Creating Opportunity of Access to Urban Infrastructure and Housing for Low - Income People" conducted during 2015-2016. The study was carried out with a grant provided by the National Research Council of Thailand and Thammasat University Fund. Thanks are due to the 
Faculty of Architecture and Planning, Thammasat University for its kind assistance in the study.

\section{REFERENCES}

[1] Department for Communities and Local Government, Transferable Lessons from the New Towns, Oxford Brookes University, 2006.

[2] Andreea, P., New Town in Modern Urbanism: Concept \& History, Journal of Urbanism Architecture Construction, 4(4), 2013.

[3] K.C., Sivaramakrishnan, New Town in India, Report on a Study of Selected New Town in the Eastern Region, Calcutta, India, 1976-1977.

[4] National Housing Authority Thailand, Bang Plee New Town Final Report, 1980.

[5] Waterman, P., Social development in new communities, Town and Country Planning 65(11), pp. 309-311, 1993.

[6] Gray, M.J., Ondaatje, E.H., Zakaras, L., Combining Service and Learning in Higher Education: Learn and Serve America, Higher Education. Summary Report. Journal of Eric, 1999.

[7] Clapson, M. et al. (eds), The Best-Laid Plans: Milton Keynes since 1967, University of Luton Press, 1998.

[8] Morton, J., From Southgate to Hallwood Park: 25 Years in the Life of a Runcorn Community, Liverpool, The Library, 1994.

[9] Beach, A., The Idea of Neighborhood 1900-50. History Today, 45(9), pp. 8-11, 1995.

[10] Southerton, D., Boundaries of Us and Them: Class, Mobility, and Identification in a New Town. Sociology, 36(1), 2002.

[11] Harman, R. \& Joy, D., Growing Elderly Problem in New Towns. Town and Country Planning, 56, pp. 298-299, 1987.

[12] Peattie, R., Some Second Thoughts on Sites-and-Services. Habitat International, 6(1/2), pp. 131-139, 1982.

[13] Cervero, R., Jobs-housing Balancing Revisited, Journal of the American Planning Association, 4, pp. 492-511, 1996.

[14] Sub district Municipality in the Bang Sao Thong, Municipal Bang Sao thong, Planning for Municipal Bang Sao thong, 1999. 